Kohl: a Journal for Body and Gender Research Vol. 3, No. 2 (Winter 2017)

\title{
On Queer Friendships That Fail
}

\author{
Priscilla Khabazi
}


I broke up with a friend today.

As queers, we like to think of chosen family, of queer friendships, of building spaces of intimacy that do not fall under the weight of normativity. And, in that intimate space of trying to build a queer friendship, somewhere along the way, I think, my friend and I, failed, because we let our incompatibilities obscure what tenderness, care, and love in queer friendships can actually mean, and what they can take on. I thought I had given all the emotional labour I could to this friend, and in return, what I felt I was getting was very far from the care and attention I want to be giving and receiving in a queer friendship. She would probably tell you it went down differently, and that is normal. Our perspectives were wildly different. But I still held on to the belief that this friendship would work itself out in spite of our differences, because of our differences.

As if our differences did not bring about enough hurdles to overcome, I also had a crush on this friend. The type of "I like you" crush that makes one gush with happiness in her presence, for no specific reason. The type of crush that made openly divulging my affection to her excessively hard to do when I was terribly terrified of being vulnerable, of the anticipation of the crush not being reciprocated. The type of crush that creates complex power dynamics and feelings of undesirability.

Which brings me back to one of the realizations that led to the friendship breakup. It was the moment I realized I was asking myself, one too many times in this friendship: is wanting deliberate care and kindness in interactions too much to ask?

I told her I liked her, and I fumbled through as we walked back home from our afternoon in the park, trying to keep it together after her rejection, all the while hearing her fill the awkward silence in the air with "do you still want to take the language lessons with me?" Language lessons, I should say, I did not ask for, but that she kept suggesting I take. "I mean, I feel weird charging you the hourly rate for them but we could do an exchange," she continued. I mumbled something to the effect of "sure, I guess," completely bewildered by her reaction.

A few days later, we discussed how I needed some time to readjust my lens to building this friendship, because she said she wanted to have me in her life and I said I wanted that too.

Over time, I managed to purge desire and the unreciprocated crush from the equation of our budding figure-it-out-as-we-go friendship. But my mistake was to not talk about that purge until it was too late, I guess. My bad for not communicating it properly.

This queer friendship breakup happened in what seemed like a slow-motion train-wreck kind of way; at the end of the day, ego got in the way of kindness, patience, and care.

It seems strange when I type it or say it out loud to myself, but I am actually grieving. I have grieved a lot of lost loved ones because of death in my life. But this kind of grief is different. Sure, this wasn't a sexually or physically intimate relationship, but fuck was it intimate in its own way. So how to stop perpetuating the false notion that only romantic relationships matter? Queer friendships matter too, and 
when done well and with careful love and kindness, they give life. Whether we like to admit it or not, we built closeness, and it is hard to witness that closeness crumble before our eyes.

So how exactly does one grieve a lost queer friendship in a whirlwind of emotional disarray? Where, along the way, did we allow ourselves to extirpate basic humanity with each other from this queer friendship?

So many more questions. Is it even fair to expect kind/gentle care to be reciprocated in the same way you dish it out? Did I build up this kind/gentle care in my mind too much? Am I as kind as I really think I am? Is it selfish to want a queer friendship to be intimate in a platonic way after you have purged the remnants of desirability from the equation? What about the lingering "perceived desire?" What about that time I slugged through our friendship when my queerness was put into question by my friend?

I ask too many questions. "Are you done with your journalistic questions now?," she would tease me every time I asked her a string of probing questions. And I secretly hate labels in queerness. I have not quite settled on where I sit in the never-ending debate of which is more inclusive of all genders and sexual expressions: bisexuality or pansexuality?

I found myself spinning dizzily on my own emotional axis when I sat there wondering how it is that our hang out moments - picnicking, going to concerts, dancing at queer dance parties, painting her apartment room together while drinking bottles of beer, walking my dog together, eating cheap grocery store-bought ice-cream to ease the workweek frustrations and blues, sitting in the park, laughing and goofily throwing small patches of grass at each other, chatting on our respective balconies while staring at the sunset when conversations dipped, or watching silly cartoons together - suddenly morphed into this ugly pushing of each other's buttons. To the point of exhaustion. To the point of no return?

Or is there a possible return after the dust settles and the tears dry up? Like the tears I wept in her presence from sheer exhaustion during an anxiety attack as she walked out of my apartment door without consoling me because, supposedly, "friendship/kindness through touch can get very complicated when romantic feelings/desire have been involved." After a week of not talking, I received a text message. No how are yous, how are you feeling nows, I am sorry we haven't spoken, I was busy but I am checking in now. Instead, I received an inquiry about whether I was watching Netflix because she could not access the account I shared with her. As if I were tech support service.

But maybe I am hypocritical too. For all my talk of kindness, I also have my own contradictions. Is it hypocritical if I say I do not believe people are disposable, yet I gave up when the buttons of acceptability were being pushed? Like the time, as a non-Arabic speaker, she insultingly said to me that Arabic had always sounded harsh to her. When I said I wondered where this preconception of my mother tongue and what I think to be a beautiful, poetic language came from, she stated that it was not a preconception, but rather a fact.

I know I am imperfect and often fast to react quickly to upsetting situations, so I know that my misgivings about her attitudes toward me got the tongue-lashing best of me, but only when my boundaries were tested to their absolute limits. So how do care, kindness, and wellbeing for all continue 
250 when someone I care for has repeatedly said or done things I found hurtful? How do I then protect my feelings and soul from being hurt while staying true to my ethos, my desire for open and tender queer friendships, without losing my sense of self? While trying to understand that we all show affection differently, and that maybe we need to be more careful with each other?

I broke up with a friend today, and failed at patience and loving care in building a queer friendship. 